Vol..5, No.2, 2019

Doi: https://doi.org/10.24198/cosmogov.v5i2.22803

http://jurnal.unpad.ac.id/cosmogov/index

\title{
IMPLIKASI DESENTRALISASI FISKAL TERHADAP KEMANDIRIAN DAERAH PASCA PEMEKARAN (Studi di Kabupaten Tulang Bawang, Tuba Barat, dan Mesuji Lampung)
}

\author{
Maulana Mukhlis \\ Syarief Makhya ${ }^{1}$ \\ ${ }^{1}$ Jurusan Ilmu Pemerintahan, Fakultas Ilmu Sosial dan Ilmu Politik, Universitas Lampung \\ Jl. Prof. Dr. Ir. Sumantri Brojonegoro No.1, Gedong Meneng, Kec. Rajabasa, Kota Bandar Lampung, \\ Lampung 35141, Indonesia \\ Email : maulanamukhlis1978@gmail.com
}

Submitted: July 28, 2019, Reviewed: November 09, 2019, Published: November 15, 2019

\begin{abstract}
ABSTRAK
Desentralisasi fiskal secara teoritis akan berimplikasi positif terhadap pertumbuhan ekonomi, pemerataan pembangunan serta efisiensi. Desentralisasi fiskal kemudian menjadi strategi yang harus dijalankan oleh pemerintah pusat dalam membangun keselarasan hubungan antar unit pemerintahan baik secara vertikal maupun horizontal. Namun bagi daerah-daerah pasca pemekaran, implikasi tersebut belum seluruhnya teruji. Pada sisi yang lain, peningkatan pertumbuhan ekonomi, pemerataan pembangunan dan kesejahteraan masyarakat adalah beberapa tujuan pemekaran daerah. Naskah ini akan menjelaskan terdapat-tidaknya implikasi desentralisasi fiskal terhadap kemandirian daerah pasca pemekaran dengan lokus di Kabupaten Tulang Bawang (sebagai kabupaten induk) serta Tulang Bawang Barat dan Mesuji (kabupaten hasil pemekaran). Penelitian ini merupakan penelitian deskriptif dengan pendekatan atau analisa kualitatif berdasarkan analisis data trend statistik. Secara faktual terbukti bahwa sepuluh tahun pasca pemekaran dilakukan, jumlah transfer dana perimbangan maupun pertumbuhan ekonomi pada tiga kabupatan pasca pemekaran selalu meningkat setiap tahunnya. Namun demikian, meskipun desentralisasi fiskal telah berimplikasi positif terhadap pertumbuhan ekonomi di kabupaten induk maupun kabupaten hasil pemekaran, tapi ternyata belum mampu mewujudkan kemandirian daerah khususnya pada sisi makro-ekonomi dan kesehatan fiskal. Hasil penelitian ini memiliki keterbatasan argumentasi karena kemandirian daerah hanya mampu dinilai pada sisi makroekonomi serta sisi kesehatan fiskal karena sejatinya terdapat aspek yang lebih komprehensif selain kedua hal itu.
\end{abstract}

Kata kunci: desentralisasi fiskal; pemekaran kabupaten; kemandirian daerah.

\begin{abstract}
Fiscal decentralization theoretically has positive implications on economy growth, development distribution, and efficiency. Fiscal decentralization should be a strategy to run by central government in building good harmonious relationships between government units vertically and horizontally. However, those implications are not yet all tested in post-administrative expansion regions, despite of some administrative expansion objectives including economy growth improvement, development distribution, and public welfare. This article would explain whether there were implications of fiscal decentralization to post-administrative expansion regional autonomy in Tulang Bawang (as the origin district to expand) and Tulang Bawang Barat and Mesuji (districts as results of administrative expansion). This was a descriptive qualitative research based on data statistic trend analysis. The fact showed that ten years after administrative expansion, amount of balanced fund transfer and economy growths in these three districts after administrative expansion increased annually. Despite of fiscal decentralization positive implications to economy growth in the origin district to expand and districts as results of administrative expansion, it was not yet able to realize regional autonomy in terms of macro-
\end{abstract}


Vol..5, No.2, 2019

Doi: https://doi.org/10.24198/cosmogov.v5i2.22803

http://jurnal.unpad.ac.id/cosmogov/index

economy and fiscal health. The limitation of this research result was that the regional autonomy was only able to assess from macro-economy and fiscal health aspects, despite of other more comprehensive aspects.

Keywords: fiscal decentralization; district administrative expansion; regional autonomy.

\section{PENDAHULUAN}

Otonomi daerah yang mulai diterapkan di Indonesia sejak tahun 2001 telah menghasilkan berbagai implikasi menyangkut aspek kelembagaan pemerintahan, hubungan antar unit pemerintahan, serta kualitas pelayanan publik. Fenomena turunan dari beberapa implikasi yang keduanya saling berhubungan seperti dua sisi mata uang adalah isu hubungan keuangan antara pemerintah pusat dengan daerah serta isu pemekaran wilayah. Khusus pada isu kedua, dari berbagai alasan yang melatarbelakangi adanya keinginan pemekaran daerah pasca penerapan otonomi daerah, salah satunya terdapat motif ekonomi (Amri P.D. dalam Nurman, 2013: p.2).

Motif tersebut berwujud pada asumsi adanya 'aliran' uang yang lebih besar dari pemerintah pusat kepada pemerintah daerah dalam bentuk transfer dana perimbangan maupun hak atau kewenangan pemungutan pajak dan retribusi di daerah. Kewenangan yang diberikan kepada daerah untuk memungut sumber pendapatan keuangan dalam bentuk pajak dan retribusi di daerah disebut dengan kebijakan desentralisasi fiskal dalam upaya mendorong kemandirian keuangan daerah dalam optimalisasi pelaksanaan fungsi-fungsi pemerintahan, baik fungsi primer seperti pelayanan maupun sekunder seperti pembangunan.

$$
\text { Secara teoritis, Menurut }
$$

Mardiasmo (dalam Putra, 2017:p.7)

desentralisasi fiskal diharapkan dapat memberi manfaat dalam hal: (i) mengurangi kesenjangan fiskal baik antara pemerintah pusat dan pemerintah daerah (vertical fiscal imbalance) maupun antar daerah yang satu dengan daerah yang lain (horizontal fiscal imbalance); (ii) meningkatkan kualitas pelayanan publik di daerah dan mengurangi kesenjangan pelayanan publik antar daerah; (iii) meningkatkan efisiensi pemanfaatan sumber daya; (iv) peningkatan tata kelola yang transparan dan akuntabel dalam pelaksanaan kegiatan pengalokasian transfer ke daerah sehingga tepat sasaran, tepat waktu, efisien, dan adil; serta (v) mendukung kesinambungan fiskal dalam kebijakan ekonomi makro.

Adapun secara praktis, menurut Abimanyu dan Megantara (dalam Sasana, 2015:p.4) desentralisasi fiskal akan mampu meningkatkan pertumbuhan ekonomi dan kesejahteraan masyarakat. Pengaruh positif desentralisasi fiskal terhadap pertumbuhan ekonomi telah dijelaskan oleh beberapa riset. Penelitian Wibowo (dalam Badrudin, 2012:p.109) menegaskan bahwa desentralisasi fiskal di Indonesia selama periode 1999-2004 secara umum 
Vol.. 5, No. 2, Bulan 2019

Doi: 10.24198/cosmogov.v2i2.xxxxx

http://jurnal.unpad.ac.id/cosmogov/index

memberikan pengaruh positif terhadap pembangunan daerah. Hasil penelitiannya memperlihatkan bahwa era baru desentralisasi fiskal yang diluncurkan sejak tahun 2001 telah memberikan dampak yang relatif lebih baik terhadap pembangunan daerah dibandingkan dengan rezim sebelumnya.

Hal di atas juga diperkuat oleh temuan Simanjuntak (2010) yang menegaskan bahwa potret perekonomian nasional dan tingkat kesejahteraan masyarakat cenderung meningkat dari tahun ke tahun sejalan dengan peningkatan sumber-sumber pendanaan daerah sebagai salah satu implikasi dari kebijakan desentralisasi fiskal.

Popularitas desentralisasi fiskal dan implikasinya dalam pencapaian berbagai tujuan di atas menjadi argumen yang kemudian banyak melatarbelakangi hasrat atau keinginan untuk melakukan pemekaran wilayah. Menurut Nurman (2013) adanya adagium "semakin banyak unit pemerintahan otonom di suatu daerah maka akan semakin besar dampaknya pada jumlah transfer dana ke daerah" menjadi salah satu motif utama dari keinginan untuk melakukan pemekaran wilayah.

Secara lebih detail, Amri dalam Nurman (2013) menyatakan bahwa terdapat dua motif utama dari tuntutan masyarakat tentang perlunya pembentukan daerah otonomi baru yang disertai dengan desentralisasi fiskal, yaitu motif ekonomi untuk mendapatkan keadilan dan pemerataan serta motif politik yaitu tuntutan demokratis untuk mengakhiri sentralisasi pengelolaan keuangan oleh pemerintah pusat. Pemekaran daerah yang disertai iming-iming insentif fiskal diasumsikan banyak pihak cukup argumentatif sebagai dasar pemekaran daerah (Tenrini, 2014).

Salah satu kabupaten di Provinsi Lampung yang melakukan pemekaran wilayah adalah Kabupaten Tulang Bawang. Pada tahun 2008 Kabupaten Tulang Bawang dimekarkan menjadi tiga daerah otonom dengan Undang Undang Nomor 49 Tahun 2008 Tentang Pembentukan Daerah Otonomi Kabupaten Mesuji dan Undang Undang Nomor 50 Tahun 2008 Tentang Pembentukan Daerah Otonom Kabupaten Tulang Bawang Barat sebagai kabupaten baru.

Selama kurun waktu sepuluh tahun pasca pemekaran hingga tahun 2018, data keuangan pada ketiga kabupaten (terakhir pada periode 2012-2017) jumlah transfer dana perimbangan dalam bentuk Dana Alokasi Umum (DAU) dan Dana Alokasi Khusus (DAK) dari pemerintah pusat kepada ketiga daerah pasca pemekaran meningkat secara kuantitas setiap tahunnya. Pertumbuhan ekonomi di ketiga kabupatan ini juga menunjukkan trend peningkatan. Namun pada sisi lain ternyata masih menunjukkan sesuatu dampak yang tidak signifikan.

Pada tabel 1 dan 2 terlihat bahwa implementasi desentralisasi fiskal di Kabupaten Tulang Bawang, Tulang Bawang Barat, dan Mesuji berpengaruh positif terhadap naiknya jumlah dana transfer dana perimbangan (khususnya Dana Alokasi Umum 〈DAU〉) sekaligus berimplikasi positif terhadap pertumbuhan ekonomi rata-rata selama periode lima tahun terakhir (tahun 2012-2017). 
Vol.. 5, No. 2, Bulan 2019

Doi: 10.24198/cosmogov.v2i2.xxxxx

http://jurnal.unpad.ac.id/cosmogov/index

Tabel 1. Jumlah Transfer DAU Tahun 2012-2017

\begin{tabular}{lcccccc}
\hline Kabupaten & \multicolumn{6}{c}{ Jumlah DAU (Tahun, dalam milyard rupiah) } \\
\cline { 2 - 7 } Tulang Bawang & 2012 & 2013 & 2014 & 2015 & 2016 & 2017 \\
Tuba Barat & 412.608 & 482,230 & 533,313 & 548,942 & 614,655 & 614,655 \\
\hline Mesuji & 423,456 & 427,765 & 439,123 & 442,703 & 464,431 & 465,116 \\
\hline \multicolumn{7}{c}{ Sumber : Data BPS, 2018}
\end{tabular}

Tabel 2. Rata-Rata Pertumbuhan Ekonomi Tahun 2012-2017

\begin{tabular}{lcccccc}
\hline Kabupaten & \multicolumn{7}{c}{ Rata-Rata Pertumbuhan Ekonomi (Tahun, dalam persen) } \\
\cline { 2 - 7 } Tulang Bawang & 2012 & 2013 & 2014 & 2015 & 2016 & 2017 \\
Tuba Barat & 5,2 & 5,4 & 5,5 & 5,0 & 5,4 & 5,7 \\
\hline Mesuji & 5,3 & 5,4 & 5,4 & 4,9 & 5,2 & 5,5 \\
\hline \multicolumn{7}{c}{ Sumber: Data BPS, 2018}
\end{tabular}

Tabel 3. Persentase Jumlah Penduduk Miskin Tahun 2012-2017

\begin{tabular}{lcccccc}
\hline Kabupaten & \multicolumn{7}{c}{ Persentase Jumlah Penduduk Miskin (Tahun, dalam persen) } \\
\cline { 2 - 6 } Tulang Bawang & 2012 & 2013 & 2014 & 2015 & 2016 & 2017 \\
Tuba Barat & 9,60 & 8,04 & 8.66 & 10,25 & 10,20 & 10,15 \\
\hline Mesuji & 6,73 & 6,31 & 7,12 & 8,23 & 8,40 & 7,80 \\
\hline \multicolumn{7}{c}{ Sumber : Data BPS (diolah), 2018}
\end{tabular}

Namun pada tabel 3 justru menunjukkan bahwa meskipun telah terjadi penurunan persentasi jumlah penduduk miskin sebagai salah satu implikasi dari pertumbuhan ekonomi tetapi penurunan besarnya jumlah penduduk miskin pada gabungan ketiga kabupatan hanya sebesar $0,7 \%$ atau masih di bawah rata-rata penurunan persentasi penduduk miskin di Provinsi Lampung sebesar 1,1\%.

Berdasarkan gambaran di atas, maka pertanyaan dalam penelitian ini, adalah apakah pelaksanaan desentralisasi fiskal pada daerah pasca pemekaran yaitu di Kabupaten Tulang Bawang, Tulang Bawang Barat, dan Mesuji Lampung berimplikasi positif terhadap kemandirian daerah sebagai wujud kinerja otonomi daerah sebagaimana digadang-gadang dalam teorinya?
Penelitian ini bertujuan untuk memberikan penjelasan implikasi atau kemampuan dari desentralisasi fiskal dalam mewujudkan kemandirian daerah sebagai tujuan utama otonomi daerah di kabupatenkabupaten pasca pemekaran, baik kabupaten induk maupun kabupaten baru hasil pemekaran.

Pada sisi urgensitas, setidaknya terdapat empat hal penting yang melatarbelakangi pentingnya riset ini. Pertama, pemekaran daerah yang dilakukan di Kabupatan Tulang Bawang, Tulang Bawang Barat, dan Kabupaten Mesuji yang diharapkan dapat meningkatkan kesejahteraan masyarakat masih menunjukkan adanya kondisi kemiskinan yang penurunannya masih berada di bawah rata-rata penurunan tingkat kemiskinan Provinsi Lampung. Kedua, desentralisasi fiskal yang meskipun 
Vol.. 5, No. 2, Bulan 2019

Doi: 10.24198/cosmogov.v2i2.xxxxx

http://jurnal.unpad.ac.id/cosmogov/index

dapat meningkatkan pertumbuhan ekonomi

Seluruh penelitian tersebut ternyata tidak berdampak signifikan pada status kapasitas fiskal ketiga kabupaten yang dikeluarkan oleh data Kementerian Keuangan karena sampai tahun 2018, ketiga kabupaten ini masih berada pada kapsitas fiskal yang rendah (PMK Nomor 119/PMK.072017 dan PMK Nomor 107/PMK.072018. Ketiga, adanya research gap yang terjadi pada berbagai studi terdahulu bahwa pengaruh positif desentralisasi fiskal hanya dijelaskan terhadap dampak pada aspek ekonomi, atau belum ditemukan adanya riset yang mengkaji relasi antara pemekaran daerah, desentralisasi fiskal, dan kemandirian daerah sebagai tujuan pemekaran daerah. Keempat, gejala pemekaran daerah secara nyata telah semakin memberatkan pemerintah pusat dalam hal peningkatan jumlah transfer dana perimbangan dalam bentuk DAU dan DAK yang cukup besar kepada daerah sementara pada sisi yang lain dampak terhadap kemandirian daerah serta kesejahteraan masyarakat di daerah belum terbukti positif secara signifikan.

Sejauh ini, hampir seluruh penelitian yang pernah dilakukan dalam kaitan dengan isu desentralisasi fiskal berfokus pada dua aspek atau kategori, yaitu pada aspek dampak desentralisasi fiskal terhadap perekonomian daerah serta pada aspek bagaimana implementasi desentralisasi fiskal di suatu daerah tertentu dijalankan. Pada aspek pertama, telah menarik perhatian banyak ahli internasional, seperti Bird and Vaillancourt (2009); Martinez-Vazquez et al. (1997); World Bank (1997); Bahl, R. W. \& Linh (1992); dan Gramlich (1993).

menyatakan bahwa dengan diserahkannya beberapa kewenangan dari pemerintah pusat kepada pemerintah daerah termasuk dalam hal pembiayaan maka pelayanan publik akan semakin efisien dan pada gilirannya mampu mendorong pertumbuhan ekonomi. Kemudian juga dengan tegas dijelaskan oleh beberapa penelitian lain yang dilakukan oleh Prud'homme (1995), Peterson (1996) serta Wekan et al. (2018) untuk kasus di negara maju, serta Zang dan Zao dalam Saputra and Mahmudi (2012) yang simpulan dalam penelitiannya di negara berkembang menegaskan bahwa terdapat pengaruh positif antara desentralisasi fiskal terhadap pertumbuhan ekonomi daerah baik di negara maju maupun negara berkembang.

Adapun pada aspek kedua tentang bagaimana desentralisasi fiskal diimplementasikan di daerah tertentu, misalnya dilakukan oleh Saputra and Mahmudi (2012), Nurman (2013), Sumardi (2014), Sasana (2015), serta Rosdyana et al. (2015). Berbagai penelitian tersebut selain mengkonfirmasi adanya pengaruh positif desentralisasi fiskal terhadap pertumbuhan ekonomi juga menyoroti tentang bagaimana desentralsiasi fiskal diimplementasikan. Kendala dan faktor yang mempengaruhi keberhasilan desentralisasi fiskal menjadi rekomendasi dari berbagai riset pada ketegori kedua ini.

Berdasarkan dua kategorisasi tersebut, maka penelitian ini memiliki state of the art yang tinggi, minimal oleh dua argumen. Pertama, bahwa hampir semua studi terdahulu hanya membahas isu desentralisasi fiskal dalam perspektif 
Vol.. 5, No. 2, Bulan 2019

Doi: 10.24198/cosmogov.v2i2.xxxxx

http://jurnal.unpad.ac.id/cosmogov/index

dampak ekonomi, padahal terdapat dampak turunan lain dikaitkan dengan tujuan otonomi daerah yakni kemandirian daerah. Kedua, terdapat relasi yang sangat erat antara pemekaran daerah, kebijakan desentralisasi fiskal, dan kemandirian daerah sebagai esensi dari tujuan otonomi daerah, namun demikian aspek kemandirian daerah ini belum banyak mendapatkan porsi kajian.

Berdasarkan latar belakang dan argumentasi tersebut dapat dinyatakan bahwa desentralisasi fiskal secara teoritis akan berimplikasi positif terhadap pertumbuhan ekonomi, pemerataan dan efisiensi pembangunan, dan kesejahteraan masyarakat. Namun kajian tentang desentralisasi fiskal sejauh ini tidak pernah membedakan antara daerah yang baru terbentuk dengan daerah yang sudah lama berdiri, padahal dari aspek apapun daerah otonom baru tentu masih membutuhkan banyak intervensi pihak luar sehingga locus pada daerah otonom baru penting untuk dilakukan. Karena itu, bagi daerah otonom baru atau bagi daerah-daerah pasca pemekaran, idealitas manfaat positif dari kebijakan desentralisasi fiskal belum seluruhnya teruji.

\section{METODE PENELITIAN}

Fokus substansi pada penelitian ini adalah implikasi desentralisasi fiskal terhadap kemandirian daerah pada daerahdaerah pasca dilakukannya pemekaran.

Menurut Halim (2001, dalam Aminuddin, 2017), terdapat dua aspek untuk menilai keberhasilan desentralisasi fiskal, yaitu aspek sisi makro-ekonomi dan aspek sisi kesehatan fiskal. Pada aspek sisi makro-ekonomi, kinerja otonomi daerah dan dampaknya terhadap indikator kunci pembangunan dapat dinilai dari beberapa variabel, yaitu pertumbuhan ekonomi, tingkat partisipasi angkatan kerja, kenaikan Indeks Pembangunan Manusia (IPM), penurunan ketimpangan, serta pengentasan kemiskinan. Adapun pada aspek kesehatan fiskal daerah dapat dilihat dari variabel pertumbuhan kapasitas fiskal, penurunan rasio ketergantungan daerah terhadap dana perimbangan, serta rasio penurunan kesenjangan atau celah fiskal daerah

Penelitian ini merupakan penelitian deskriptif dengan pendekatan atau analisa kualitatif berdasarkan data trend statistik. Data-data dalam bentuk angka tidak untuk dicari hubungan atau pengaruhnya secara operasional dalam variebal bebas dan variabel terikat. Data berbentuk angka tersebut dijadikan dasar untuk menghasilkan analisa kualitatif dalam bentuk kategorisasi implikasi pada kemandirian daerah, yaitu pada aspek makro-ekonomi dan aspek kesehatan fiskal.

Data sekunder yang diperoleh melalui penelusuran RPJMD serta laporan realisasi keuangan daerah serta data BPS yang relevan dengan fokus penelitian menjadi data utama yang dipakai dalam penelitian. Sedangkan data yang diperoleh dari wawancara dengan beberapa informan yaitu Kepala Badan Perencanaan Pembangunan Daerah serta Kepala Badan Pengelola Keuangan dan Aset Daerah pada tiga kabupaten lokasi penelitian menjadi landasan untuk menjelaskan faktor yang mempengaruhi terdapat tidaknya implikasi 
Vol.. 5, No. 2, Bulan 2019

Doi: 10.24198/cosmogov.v2i2.xxxxx

http://jurnal.unpad.ac.id/cosmogov/index

desentralisasi fiskal terhadap kemandirian

Desentralisasi fiskal dan otonomi daerah.

Validasi untuk meyakinkan data dilakukan dengan melakukan triangulasi sumber dan metode sebagaimana dijelaskan Wiersma (dalam Bachri, 2010). Triangulasi sumber dipergunakan dengan cara membandingkan informasi yang didapatkan dengan sumber yang berbeda. Adapun triangulasi metode dilakukan dengan menggunakan bukan hanya satu teknik pengumpulan data yakni teknik wawancara dan dokumentasi untuk mendapatkan data yang sama.

\section{HASIL DAN PEMBAHASAN}

Hubungan keuangan antara pemerintah pusat dengan daerah yang secara formal mulai diatur dalam Undang Undang Nomor 33 Tahun 2004 tentang Perimbangan Keuangan antara Pemerintah Pusat dengan Daerah dan secara praktik diwujudkan dalam bentuk transfer dana perimbangan serta hak dan kewenangan memungut sumber pendapatan di daerah disebut sebagai desentralisasi fiskal.

Menurut Bahl dan Linn (1992) desentralisasi fiskal berarti desentralisasi dari pemerintahan, alokasi pengeluaran dan mobilisasi penerimaan daerah. Bahl juga menyebutkan bahwa bentuk desentralisasi fiskal sangat bervariasi tergantung sistem pemerintahannya. Pada satu titik ekstrim tertentu negara cenderung membatasi desentralisasi sehingga pemerintah daerah tidak bisa leluasa melakukan pembiayaan dan pelayanan publik. Sedangkan di titik ekstrim lainnya, pemerintah lokal diberikan kekuasaan penuh dalam mengelola sumber-sumber keuangan di daerahnya.

daerah berikutnya menjadi konsep yang selalu seiring sejalan; dalam artian bahwa pelaksanaan otonomi daerah salah satunya diwujudkan dalam bentuk desentralisasi fiskal dan sebaliknya bahwa tingginya derajat desentralisasi fiskal akan menjadi indikator dari keberhasilan pelaksanaan otonomi daerah.

Desentralisasi fiskal adalah pilihan wajib bagi suatu negara berbentuk kesatuan untuk membangun pola hubungan yang baik dan selaras antara unit pemerintahan baik secara vertikal maupun horizontal. Secara vertikal, hubungan pemerintah pusat dengan pemerintah daerah akan berjalan harmonis apabila daerah merasa bahwa kewenangan untuk mencari sumber pendanaan di daerah sesuai dengan urusan pemerintahan yang diembannya. Adapun secara horizontal, desentralisasi fiskal yang adil yang diberikan oleh pemerintah pusat akan meniadakan kesenjangan yang terlalu lebar antar satu daerah dengan daerah lain, baik antar provinsi maupun antar kabupaten/kota dalam satu wilayah provinsi.

Secara teori, salah satu indikator keberhasilan pembangunan daerah adalah jumlah penduduk miskin, dalam artian bahwa penurunan jumlah penduduk miskin adalah indikasi dari keberhasilan pembangunan, begitu pula sebaliknya bahwa kenaikan jumlah penduduk miskin adalah indikasi dari kegagalan pembangunan. Oleh karena itu, jumlah penduduk miskin adalah salah satu ukuran atau dampak akhir dari penyelenggaraan pemerintahan. Keberhasilan pembangunan daerah tidak bisa hanya dibahas dalam 
Vol.. 5, No. 2, Bulan 2019

Doi: 10.24198/cosmogov.v2i2.xxxxx

http://jurnal.unpad.ac.id/cosmogov/index

konteks dampak namun juga terkait pada aspek penyebab atau pendorongnya. Dalam konteks ini, implementasi desentralisasi fiskal berada pada posisi penyebab atau pendorong keberhasilan otonomi daerah dimaksud.

Sebagai tujuan atau dampak antara, desentralisasi fiskal adalah salah satu strategi utama untuk mendorong terwujudnya kemampuan keuangan daerah sehingga daerah mampu untuk menyelenggarakan pembangunan dan pelaksanaan fungsi-fungsi pemerintahan dengan maksimal. Berikutnya desentralisasi fiskal sekaligus dapat menjadi jalan untuk mewujudkan kemandirian daerah sebagai tujuan akhir dari pelaksanaan otonomi daerah. Dalam konteks tersebut maka terdapat relasi yang sangat erat antara desentralisasi fiskal dan kemandirian daerah sehingga idealnya desentralisasi fiskal harus mampu meningkatkan kemandirian daerah bukan hanya pada aspek pertumbuhan ekonomi semata.

Indikator kemandirian daerah sebagai implikasi desentralisasi fiskal dalam penelitian ini akan dijelaskan pada aspek makro-ekonomi dan aspek kesehatan fiskal.

\section{Kemandirian Daerah Pada Aspek} Makro-Ekonomi

Pada aspek makro-ekonomi, kemandirian daerah sebagai indikator kinerja otonomi daerah di Kabupaten Tulang Bawang, Tulang Bawang Barat, dan Mesuji akan dinilai dari beberapa variabel, yaitu pertumbuhan ekonomi, peningkatan angka partisipasi angkatan kerja, kenaikan IPM, penurunan ketimpangan, serta pengentasan kemiskinan.

Tabel 4 menunjukkan secara faktual bahwa dalam kurun waktu tiga tahun terakhir, jumlah DAU sebagai komponen utama dana perimbangan yang diterima oleh Kabupaten Tulang Bawang, Tulang Bawang Barat, maupun Mesuji selalu mengalami peningkatan setiap tahun. Dalam konteks ini jelas nyata bahwa iming-iming insentif fiskal sebagai implikasi pemekaran daerah benar terbukti. Akumulasi jumlah DAU pada tiga kabupaten pasca pemekaran akan sangat lebih tinggi jika dibandingkan dengan DAU yang diterima oleh Kabupaten Tulang Bawang sebelum terjadi pemekaran.

\begin{tabular}{lll}
\multicolumn{1}{c}{ Dalam } & perspektif & pengelola \\
keuangan & maupun & perencana \\
pembangunan & pada tiga & kabupaten
\end{tabular}
seluruhnya menyebutkan terdapat implikasi positif dari pemekaran daerah dengan peningkatan jumlah uang yang dikelola oleh pemerintah daerah.

Analisis berikutnya menyangkut relasi antara kenaikan jumlah uang yang dikelola oleh daerah terhadap pertumbuhan ekonomi dan implikasi turunannya.

Data pada tabel 5 menunjukkan rata-ratapertumbuhan ekonomi pada tiga kabupaten pasca pemekaran. Tabel 6 berikutnya menunjukkan tingkat partisipasi angkatan kerja, sedangkan pada tabel 7 dan 8 akan diuraikan perkembangan nilai IPM pada masing-masing kabupaten dan perbandingannya dengan kabupaten/kota lainnya di Provinsi Lampung. Adapun tabel 9 akan menggambarkan jumlah 
Vol.. 5, No. 2, Bulan 2019

Doi: 10.24198/cosmogov.v2i2.xxxxx

http://jurnal.unpad.ac.id/cosmogov/index

penduduk miskin di tiga lokasi penelitian,

sebagai implikasi terakhir dari yaitu Kabupaten Tulang Bawang, Tulang desentralisasi fiskal pada aspek makroBawang Barat, dan Mesuji dalam kurun ekonomi. waktu tiga tahun terakhir (2015-2017)

Tabel 4. Jumlah DAU Tiga Tahun Terakhir Pada Tiga Kabupaten Pasca Pemekaran

\begin{tabular}{cccc}
\hline Kabupaten & DAU Tahun 2015 & DAU Tahun 2016 & DAU Tahun 2017 \\
\hline Tulang Bawang & 548,942 & 614,655 & 614,655 \\
Tuba Barat & 442,703 & 464,431 & 465,116 \\
\hline Mesuji & 429,897 & 447,672 & 448,282 \\
\hline \multicolumn{4}{c}{ Sumber : Data BPS (diolah), 2018 }
\end{tabular}

Tabel 5. Data Pertumbuhan Ekonomi Tiga Kabupaten Pasca Pemekaran

\begin{tabular}{cccc}
\hline Kabupaten & $2015(\%)$ & $2016(\%)$ & $2017(\%)$ \\
\hline Tulang Bawang & 5,0 & 5,4 & 5,7 \\
Tuba Barat & 4,9 & 5,2 & 5,5 \\
\hline Mesuji & 5,4 & 5,1 & 5,3 \\
\hline \multicolumn{4}{c}{ Sumber: Data BPS , 2019 }
\end{tabular}

Berdasarkan tabel 5 dapat terlihat bahwa rata-rata pertumbuhan ekonomi selama kurun waktu tiga tahun terakhir di tiga kabupaten adalah 5,2\%. Apabila dihitung tiap tahun maka terjadi peningkatan rata-rata sebesar 5,1\% (2015), meningkat menjadi 5,2\% (2016) dan 5,5\% (2017). Data tersebut secara tegas menunjukkan bahwa secara umum terdapat relasi yang positif antara peningkatan jumlah DAU yang diterima daerah dengan pertumbuhan ekonomi daerah tersebut. Temuan Kamaroellah (2017), Sijabat et.al. (2014), Sasana (2015), maupun Saputra and Mahmudi (2012) terkonfirmasi kesesuaiannya dengan temuan di Tulang Bawang dan Tulang Bawang Barat.

Namun demikian keunikan atau ketimpangan terjadi di Kabupaten Mesuji di mana pertumbuhan ekonomi pada kabupaten ini justru mengalami penurunan dari tahun 2015 ke tahun 2016. Data
Rencana Pembangunan Jangka Menengah Daerah (RPJMD) Kabupaten Mesuji tahun 2017-2022 menjelaskan bahwa tingkat pertumbuhan ekonomi maupun dipengaruhi oleh fluktuasi setiap sektor ekonomi di Mesujiyang terutama mencakup sektor pertanian; pertambangan dan penggalian; industri pengolahan; listrik, gas, dan air bersih; konstruksi; perdagangan, restoran dan hotel; pengangkutan dan komunikasi; lembaga keuangan; dan jasa-jasa lainnya.

Sektor partanian memberikan kontribusi sangat besar bagi kabupaten ini. Dengan kondisi harga-harga komoditi perkebunan terutama kelapa sawit dan karet yang tidak stabil selama kurun waktu tahun 2015-2016 menjadi salah satu penyebab menurunnya tingkat pertumbuhan ekonomi meskipun kembali mengalami trend positif pada tahun 2017. 
Vol.. 5, No. 2, Bulan 2019

Doi: 10.24198/cosmogov.v2i2.xxxxx

http://jurnal.unpad.ac.id/cosmogov/index

Fakta ketidakmampuan Mesuji sebagai daerah otonom baru meningkatkan pertumbuhan ekonomi tentu membantah pendapat Abimanyu dan Megantara (2009) dalam Sasana (2015) bahwa desentralisasi fiskal akan mampu meningkatkan pertumbuhan ekonomi dan kesejahteraan masyarakat, karena pemerintah daerah akan lebih efisien dalam produksi dan penyediaan barang-barang publik.

Adapun peningkatan pertumbuhan ekonomi yang terjadi di Kabupaten Tulang Bawang dan Tulang Bawang Barat selain juga selaras dengan pendapat Abimanyu dan Megantara (2009) di atas, juga mengkonfirmasi argumentasi yang dibuat oleh World Bank (1997), bahwa desentralisasi fiskal dapat mendorong pertumbuhan ekonomi secara langsung. Terdapat tiga mekanisme dampak desentralisasi fiskal terhadap pertumbuhan ekonomi salah satunya bahwa desentralisasi fiskal akan meningkatkan efisiensi ekonomi di sektor pengeluaran pemerintah dan efek dinamis tersebut akan mendorong pertumbuhan ekonomi. Oleh karena itu, terdapat hubungan positif antara desentralisasi fiskal dengan pertumbuhan ekonomi.

Pertumbuhan ekonomi sangat dipengaruhi oleh produktifitas tenaga kerja yang bekerja sehingga pertumbuhan ekonomi idealnya mampu mengurangi tingkat pengangguran yang dapat dikur dengan tingkat partisipasi angkatan kerja (TPAK). TPAK merupakan rasio antara banyaknya angkatan kerja dengan banyaknya penduduk usia kerja di suatu daerah. TPAK ini dipergunakan sebagai indikator ketenagakerjaan untuk memberikan gambaran tentang penduduk yang aktif secara ekonomi dalam kegiatan sehari-hari merujuk pada suatu waktu atau periode tertentu. Angkatan kerja adalah penduduk usia kerja (15 tahun dan lebih) yang bekerja atau punya pekerjaan atau punya pekerjaan namun sementara tidak bekerja dan pengangguran. Gambaran TPAK pada tiga kabupaten pasca pemekaran dijelaskan pada tabel 6.

Tabel 6 menjelaskan bahwa terjadi kesenjangan yang cukup lebar antara kabupaten satu dengan kabupaten lainnya dalam hal TPAK. Kabupaten Mesuji sebagaimana terjadi pada tingkat pertumbuhan ekonomi- memiliki TPAK paling rendah sehingga terdapat angka pengangguran paling tinggi di antara dua kabupaten lainnya.

Tingginya pengangguran di Kabupaten Mesuji terdiri atas pengangguran terbuka baik sukarela (mereka yang tidak mau bekerja karena mengharapkan pekerjaan yang lebih baik) maupun secara terpaksa (mereka yang mau bekerja tetapi tidak memperoleh pekerjaan) serta kategori setengah menganggur yaitu mereka yang bekerja lamanya (hari, minggu, musiman) kurang dari yang mereka kerjakan.

Faktor ketenagakerjaan yang berimplikasi terhadap tercapainya standar hidup layak bersama dengan faktor pendidikan dan kesehatan menjadi variabel kinerja otonomi daerah berikutnya. Indikator standar hidup layak, pendidikan, dan kesehatan tersebut menjadi variabel penetapan IPM. Secara konsep, IPM merupakan indeks komposit yang dihitung sebagai rata-rata-sederhana dari tiga indeks 
Vol.. 5, No. 2, Bulan 2019

Doi: 10.24198/cosmogov.v2i2.xxxxx

http://jurnal.unpad.ac.id/cosmogov/index

yang menggambarkan kemampuan dasar manusia dalam memperluas pilihanpilihan, yaitu: Indeks Harapan Hidup, Indeks Pendidikan, dan Indeks Standar
Hidup Layak (Syaifullah and Malik, 2017).

Perkembangan nilai IPM pada tiga

kabupaten pasca pemekaran sebagaimana terlihat
7.

Tabel 6. Tingkat PartisipasiAngkatan Kerja Tiga Kabupaten Pasca Pemekaran

\begin{tabular}{cccc}
\hline Kabupaten & $2015(\%)$ & $2016(\%)$ & $2017(\%)$ \\
\hline Tulang Bawang & 63,13 & 65,35 & 67,17 \\
Tuba Barat & 72,33 & 67,95 & 68.17 \\
\hline Mesuji & 42,27 & 43,63 & 44,07 \\
\hline \multicolumn{4}{c}{ Sumber: RPJMD Kabupaten, diolah. }
\end{tabular}

Tabel 7. Perkembangan Nilai IPM Tiga Kabupaten Pasca Pemekaran

\begin{tabular}{cccc}
\hline Kabupaten & 2015 & 2016 & 2017 \\
\hline Tulang Bawang & 66,08 & 66,74 & 67,35 \\
Tuba Barat & 63,01 & 63,77 & 64,58 \\
\hline Mesuji & 59,79 & 60,72 & 61,10 \\
\hline \multicolumn{4}{c}{ Sumber : Data BPS, 2019 }
\end{tabular}

Berdasarkan tabel 7 dapat penduduk miskin setiap tahun dijelaskan bahwa kondisi ini adalah kondisi menunjukkan keberhasilan desentralisasi yang memang paling ideal dan harus terwujud di mana kabupaten induk memiliki tingkat IPM paling baik dibandingkan dengan kabupaten hasil pemekaran. Berbeda dengan data pada tabel 5 dan tabel 6 yang mengalami kondisi abnormal di mana kabupaten hasil pemekaran justru lebih baik dibanding kabupaten induk, pada tabel 7 terlihat bahwa kabupaten induk memiliki nilai IPM paling tinggi dibandingkan dua kabupaten hasil pemekaran. Namun demikian, dalam skala Provinsi Lampung, ketiga kabupaten ini belum mampu beranjak dari lima kabupaten terendah di Provinsi Lampung, sebagaimana terlihat pada tabel 8 .

Variabel terakhir menyangkut kinerja otonomi daerah pada aspek atau sisi makro-ekonomi adalah jumlah penduduk miskin. Trend berkurangnya jumlah fiskal dalam mewujudkan tujuannya dan begitu pula sebaliknya. Tabel 9 menunjukkan persentase jumlah penduduk miskin di Kabupaten Tulang Bawang, Tuba Barat, dan Mesuji.

Pada tabel 9 keunikan justru terjadi ketika kabupaten induk (Kabupaten Tulang Bawang) memiliki jumlah penduduk miskin terbesar dibanding dua kabupaten lainnya hasil pemekaran. Hal tersebut sangat tidak sebanding dengan tingginya IPM yang dimiliki oleh Kabupaten Tulang Bawang. Posisi Kabupaten Mesuji, dalam variabel jumlah penduduk miskin justru relatif paling rendah dibandingkan dua kabupaten lainnya meskipun pertumbuhan ekonomi kabupaten Mesuji ini paling rendah dibanding dengan dua kabupaten lainnya. 
Vol.. 5, No. 2, Bulan 2019

Doi: 10.24198/cosmogov.v2i2.xxxxx

http://jurnal.unpad.ac.id/cosmogov/index

Tabel 8. Perbandingan IPM Kabupaten/Kota se Provinsi Lampung

\begin{tabular}{|c|l|c|c|c}
\hline No. & \multicolumn{1}{|c|}{ Kabupaten/Kota } & 2014 & 2015 & 2016 \\
\hline 1 & Kota Metro & 74,98 & 75,10 & 75,45 \\
\hline 2 & Kota Bandar Lampung & 74,34 & 74,81 & 75,34 \\
\hline & INDONESIA & 68,90 & 69,55 & 70,18 \\
\hline 3 & Lampung Tengah & 67,07 & 67,61 & 68,33 \\
\hline 4 & Pringsewu & 66,58 & 67,55 & 68,26 \\
\hline 5 & Lampung Timur & 66,42 & 67,10 & 67,88 \\
\hline & LAMPUNG & 66,42 & 66,95 & 67,65 \\
\hline 6 & Lulang Bawang & 65,83 & 66,08 & 6,74 \\
\hline 7 & Lampung Selatan & 63,75 & 65,22 & 6,19 \\
\hline 8 & Wampung Utara & 64,89 & 65,20 & 65,95 \\
\hline 9 & Lay Kanan & 64,32 & 65,18 & 65,74 \\
\hline 11 & Tampung Barat & 63,54 & 64,54 & 65,45 \\
\hline 12 & Tulang Bawang Barat & 62,67 & 63,66 & 64,41 \\
\hline 13 & Pesawaran & 62,46 & 63,01 & 63,77 \\
\hline 14 & Pesisir Barat & 61,70 & 62,70 & 63,47 \\
\hline 15 & Mesuji & 59,76 & 60,55 & 61,50 \\
\hline
\end{tabular}

Sumber: Data BPS, 2019.

Tabel 9. Jumlah Penduduk Miskin Tiga Kabupaten Pasca Pemekaran

\begin{tabular}{cccc}
\hline Kabupaten & $2015(\%)$ & $2016(\%)$ & $2017(\%)$ \\
\hline Tulang Bawang & 10,25 & 10,20 & 10,15 \\
Tuba Barat & 8,23 & 8,40 & 7,80 \\
\hline Mesuji & 8,20 & 8,00 & 8,00 \\
\hline \multicolumn{4}{c}{ Sumber: RPJMD Kabupaten, diolah. }
\end{tabular}

Kinerja Otonomi Daerah Pada Aspek Kesehatan Fiskal Daerah

Dalam rangka menjalankan fungsifungsi dan kewenangan yang diekspresikan dalam wujud kebutuhan fiskal, setiap daerah memiliki dan dibekali kapasitas keuangan. Kinerja otonomi daerah dan dampaknya terhadap kesehatan fiskal daerah sebagai tujuan desentralisasi fiskal dapat dilihat dari variabel rasio pertumbuhan kapasitas fiskal, tingkat penurunan ketergantungan dana perimbangan, sertapenurunan kesenjangan atau celah fiskal.

Secara konsep, yang dimaksud dengan kapasitas fiskal daerah adalah kemampuan pemerintah daerah untuk menghimpun pendapatan berdasarkan sumber-sumber yang dimilikinya atau disebut dengan derajat otonomi fiskal. Munir(dalam Sijabat (2016), menjelaskan bahwa salah satu ciri yang menunjukkan sebuah daerah mampu mandiri atau berotonomi terletak pada kemampuan keuangan daerahnya.Dengan demikian, daerah otonom harus memiliki hak atau kewenangan serta kemampuan untuk menggali sumber keuangan sendiri, mengelola, serta menggunakannya untuk mampu membiayai penyelenggaraan pemerintahan di daerahnya. Salah satu tolak ukur kemampuan keuangan daerah ditunjukkan dalam skala interval Derajat Otonomi Fiskal (DOF) sebagaimana Tabel 10. Apabila persentase jumlah Pendapatan Asli Daerah (PAD) lebih dari 50\% dibanding total pendapatan daerah, maka DOF daerah tersebut sangat baik, interval 40,01 s.d 50\% maka kemampuan keuangan daerah tersebut baik, dan seterusnya. 
Vol.. 5, No. 2, Bulan 2019

Doi: 10.24198/cosmogov.v2i2.xxxxx

http://jurnal.unpad.ac.id/cosmogov/index

Tabel 10. Rasio Derajat Otonomi Fiskal

\begin{tabular}{|c|c|}
\hline PAD/TPD (\%) & Kemampmam \\
\hline $0,00-10,00$ & Sangat Kurang \\
\hline $10,01-20,00$ & Kurang \\
\hline $20,01-30,00$ & Sedang \\
\hline $30,01-40,00$ & Cukup \\
\hline $40,01-50,00$ & Baik \\
\hline 750,01 & Sangatbaik \\
\hline
\end{tabular}

Sumber: Munir \& Tangkilisan, 2004.

Tabel 11. Derajat Otonomi Fiskal Tiga Kabupaten Pasca Pemekaran

\begin{tabular}{cccc}
\hline Kabupaten & $2015(\%)$ & $2016(\%)$ & $2017(\%)$ \\
\hline Tulang Bawang & 3,45 & 2,31 & 3,52 \\
Tuba Barat & 10,52 & 12,85 & 22,79 \\
\hline Mesuji & 3,67 & 4,86 & 4,84 \\
\hline \multicolumn{5}{c}{ Sumber: BPS, data diolah, 2019. }
\end{tabular}

Penilaian atau penghitungan terhadap jumlah PAD di Kabupaten Tulang Bawang, Tulang Bawang Barat dan Mesuji dibandingkan atau dibagi dengan total pendapatan daerah pada kurun waktu tahun anggaran 2015-2017 didapatkan data DOF sebagaimana tabel 11. Data pada tabel 11 menunjukkan bahwa Kabupaten Tulang Bawang Barat sebagai daerah oronom baru memiliki kemampuan keuangan kurang karena hanya memiliki DOF rata-rata $15,3 \%$, sedangkan kabupaten induk (Tulang Bawang, sebesar rata-rata hanya 3,09\%) dan Kabupaten Mesuji (rata-rata 4,45\%) bahkan termasuk kabupaten dengan kemampuan keuangan daerah kategori sangat kurang.
Berikutnya, pada variabel kedua yaitu penurunan ketergantungan dana perimbangan dapat dinilai dari keadaan di mana jumlah PAD lebih besar daripada bantuan dari pemerintah pusat yang terdiri atas DAU, DAK, dana bantuan provinsi, serta dana pinjaman (jika ada). Apabila jumlah PAD lebih besar daripada bantuan dari pemerintah pusat maka ketergantungan pemerintah daerah terhadap pemerintah pusat semakin kecil. Dalam bahasa lain, Semakin rendah ketergantungannya, maka derajat desentralisasi fiskal semakin tinggi (Simanjuntak, 2010). Menurut Purba (2012), relasi antara kemampuan keuangan dengan hubungan pemerintah pusat dengan daerah sebagaimana tabel 12 .

Tabel 12. Rasio Kemampuan Fiskal

\begin{tabular}{|c|c|c|}
\hline $\begin{array}{c}\text { Kemampuam } \\
\text { keuamgan }\end{array}$ & $\begin{array}{c}\text { Rasio } \\
\text { Kemaixian }\end{array}$ & $\begin{array}{c}\text { Pola } \\
\text { hubumgan }\end{array}$ \\
\hline Rendah sekali & $0-25$ & Tastruktif \\
\hline Rendah & $25-50$ & Konsultatif \\
\hline Sedang & $50-75$ & Partisipatif \\
\hline Tinggi & $75-100$ & Delegatif \\
\hline
\end{tabular}

Berdasarkan penghitungan terhadap jumlah PAD di Kabupaten Tulang Bawang, Tulang Bawang Barat dan Mesuji dibandingkan atau dibagi dengan total pendapatan daerah yang bersumber dari bantuan pemerintah pusat dan provinsi pada kurun waktu tahun anggaran 20152017 didapatkan data kemampuan daerah 
Vol.. 5, No. 2, Bulan 2019

Doi: 10.24198/cosmogov.v2i2.xxxxx

http://jurnal.unpad.ac.id/cosmogov/index

sebagaimana tabel 13. Data pada tabel 13 ini menunjukkan bahwa seluruh kabupaten ini memiliki kemampuan fiskal yang rendah sekali karena jauh di bawah 25\%

Terakhir, variabel kesenjangan fiskal atau celah fiskal adalahselisih antara kebutuhan fiskal daerah dikurangi dengan kapasitas fiskal yang yang dimiliki daerah Simanjuntak (2010). Tabel 11 maupun 13 keduanya menunjukkan bahwa jika dibandingkan dengan kebutuhan daerah, kemampuan keuangan daerah ketiga kabupaten ini masih sangat jauh. PAD yang jumlahnya sangat rendah di bawah kebutuhan fiskal bahkan jauh di bawah kebutuhan untuk membiayai belanja rutin mengindikasikan bahwa celah fiskal pada ketiga kabupaten ini sangat tinggi. Artinya, ketergantungan keuangan dari Kabupaten Tulang Bawang, Tulang Bawang Barat dan Mesuji kepada pemerintah pusat sangat tinggi sehingga derajat desentralisasi fiskal pada ketiga kabupaten ini sangat rendah.

Tabel 13. Kemampuan Fiskal Daerah Tiga Daerah Pasca Pemekaran

\begin{tabular}{cccc}
\hline Kabupaten & $2015(\%)$ & $2016(\%)$ & $2017(\%)$ \\
\hline Tulang Bawang & 4,81 & 3,16 & 5,04 \\
Tuba Barat & 3,63 & 2,66 & 3,38 \\
\hline Mesuji & 4,73 & 5,07 & 6,50 \\
\hline \multicolumn{5}{c}{ Sumber: BPS, data diolah, 2019.}
\end{tabular}

Pada saat yang sama, hasil penelitian juga menunjukkan bahwa desentralisasi fiskal lebih dimaknai oleh stakeholders di daerah sebagai sekadar penyerahan sejumlah uang ke daerah sehingga berbagai strategi yang ditempuh dalam pengelolaan keuangan daerah lebih dominan pada upaya agar jumlah DAU maupun DAK dapat semakin besar masuk ke daerah setiap tahun. Dalam kata lain para pengelola keuangan di daerah lebih berfokus pemikiran dan upayanya pada seberapa besar jumlah uang dari pusat dapat masuk ke daerah sehingga orientasi intensifikasi perolehan pendapatan daerah melalui peningkatan dana perimbangan (DAU dan DAK atau bantuan) lebih dominan dibanding strategi inovasi pada upaya peningkatan PAD baik pada sektor pajak maupun retribusi daerah.

Selain itu, pemberian wewenang kepada daerah untuk memungut sumber pendapatan dalam bentuk pajak dan retribusi daerah dominan dilakukan secara pragmatis demi tujuan pendapatan daripada pelayanan. Indikasinya tercermin dalam bentuk lebih dari 50\% Peraturan Daerah (Perda) yang dihasilkan di tiga kabupaten ini adalah Perda yang berimplikasi kepada tercapainya target pendapatan dari sektor pajak dan retribusi daerah pada berbagai urusan atau kewenangan tertentu.

\section{SIMPULAN}

Desentralisasi fiskal idealnya harus menunjukkan hasil yang linier antar satu variabel dengan variabel berikutnya. Namun, pada kasus tiga kabupaten pasca pemekaran dalam riset ini yaitu Kabupaten Tulang Bawang, Tulang Bawang Barat dan Mesuji idealitas tersebut tidak selamanya terkonfirmasi.

Berdasarkan hasil penelitian secara argumentatif dapat disimpulkan bahwa 
Vol.. 5, No. 2, Bulan 2019

Doi: 10.24198/cosmogov.v2i2.xxxxx

http://jurnal.unpad.ac.id/cosmogov/index

implementasi desentralisasi fiskal di Kabupaten Tulang Bawang, Tulang Bawang Barat dan Mesuji selama sepuluh tahun pasca pemekaran belum memberikan implikasi positif terhadap ketercapaian idealitas tujuan kebijakan desentralisasi fiskal dalam mewujudkan kemandirian daerah.

Dalam arti lain, relasi yang harus terbangun antara desentralisasi fiskal dengan kemandirian daerah, pengurangan kemiskinan, dan peningkatan kesejahteraan masyarakat belum merupakan hubungan yang selalu sejalan. Meskipun desentralisasi fiskal telah memberikan kontribusi pada peningkatan kemampuan keuangan di daerah relatif lebih besar disbanding sebelum pemekaran, namun derajat ketergantungan pemerintah daerah kepada pemerintah pusat tidak semakin menurun

Berdasarkan temuan tersebut, perlu dibangun kebijakan baru tentang model hubungan keuangan antara pemerintah pusat dengan pemerintah daerah misalnya dengan pengembangan teori asimetri desentralisasi fiskal. Diperlukan model alternatif tentang bagaimana desentralisasi fiskal diterapkan dengan secara berbeda berbasis kondisi daerah otonom (baru terbentuk atau sudah lama berdiri) sehingga tujuan kemandirian daerah dapat diwujudkan melalui kebijakan desentralisasi fiskal ini.

\section{DAFTAR PUSTAKA}

Aminuddin, Muzdhalifa Rukmayana. (2017). Pengaruh Kemandirian Fiskal Terhadap Pertumbuhan Ekonomi Kabupaten/Kota Di Provinsi Maluku. Fakultas
Ekonomi Dan Bisnis Universitas Brawijaya.

Bachri, Bachtiar S. (2010). Meyakinkan Validitas Data Melalui Triangulasi Pada Penelitian Kualitatif. Fakultas Ilmu Pendidikan, Universitas Negeri Surabaya, 10(1). Retrieved from

http://yusuf.staff.ub.ac.id/files/2012 /11/meyakinkan-validitas-datamelalui-triangulasi-padapenelitian-kualitatif.pdf.

Badrudin, Rudi. (2012). Pengaruh Desentralisasi Fiskal Terhadap Belanja Modal, Pertumbuhan Ekonomi, Dan Kesejahteraan Masyarakat Kabupaten/Kota Di Provinsi Jawa Tengah. Universitas Airlangga, Surabaya.

Bahl, R. W. \& Linh, J. (1992). Urban Finance in Development Countries.

Bird, Richard M., and François Vaillancourt. (2009). Fiscal Decentralization in Developing Countries: An Overview. Fiscal Decentralization in Developing Countries, pp.1-48, doi:10.1017/cbo9780511559815.0 02 .

Gramlich, Edward M. (1993). A Policy Maker's Guide to Fiscal Decentralization. National Tax Journal, 46(2).

Kamaroellah, R. Agoes. (2017). Analisis Tingkat Kemampuan Keuangan Daerah Dalam Mendukung Pelaksanaan Otonomi Daerah. Jurnal Nuansa, 14(1).

Martinez-Vazquez, Jorge, et al. (1997). Fiscal Decentralization, Economic Growth, and Democratic Governance. Georgia State University, International Studies Program Working Paper. Retrieved from https://ideas.repec.org/p/ays/ispwps /paper9707.html.

Nurman, Muhammad Andry. (2013). Pengaruh Desentralisasi Fiskal Terhadap Disparitas Pendapatan Regional Di Indonesia Tahun 
Vol.. 5, No. 2, Bulan 2019

Doi: 10.24198/cosmogov.v2i2.xxxxx

http://jurnal.unpad.ac.id/cosmogov/index

2001-2008. Jurnal Organisasi Dan Manajemen, 9(1).

Peterson, George E. (1996). Decentralization in Latin AmericaLearning through Experience. The World Bank. Retrieved from http://documents.worldbank.org/cu rated/en/310921468753023954/pdf /multi-page.pdf.

Prud'homme, R. (1995). On the Danger of Decentralization. The World Bank Research Observer, 10(2). Retrieved from https://www.semanticscholar.org/p aper/The-dangers-ofdecentralization-

Prud\%27homme/27e1a79228382f 04bb3c272de9152a37dda3df42.

Purba, Ris Ulina Dewi Sartika, Universitas Sumatera. (2012). Analisis Kemampuan Keuangan Daerah Di Kabupaten/Kota Di Sumatera Utara. Fakultas Ekonomi, Universitas Sumatera Utara.

Putra, Ferdian. (2017). Pengaruh Desentralisasi Fiskal, Luas Wilayah, Dan Sisa Lebih Pembiayaaan Anggaran Terhadap Pengalokasian Belanja Modal (Studi Empiris Pada Kabupaten Dan Kota Di Provinsi Sumatera Barat Tahun 2010-2014). Universitas Negeri Padang.

Rosdyana, Dewi, et al. (2015). Pengaruh Desentralisasi Fiskal Terhadap Pertumbuhan Ekonomi Daerah Dan Ketimpangan Pendapatan Di Pulau Jawa Tahun 2009-2013. Lembaga Penelitian Universitas Gunadarma, VI. doi:10.13140/RG.2.1.3357.2881.

Saputra, Bambang, and Mahmudi. (2012). Pengaruh Desentralisasi Fiskal Terhadap Pertumbuhan Ekonomi Dan Kesejahteraan Masyarakat. Jurnal Akuntansi Dan Auditing Indonesia, 16(2), pp. 185-99.

Sasana, Hadi. (2015). Dampak Implementasi Desentralisasi Fiskal Terhadap Pertumbuhan Ekonomi Dan Stabilitas Harga Di Provinsi Di Indonesia. MEDIA EKONOMI
DAN MANAJEMEN, 30(2), pp. 161-77.

Sijabat, Mentari. (2014). Analisis Kinerja Keuangan Serta Kemampuan Keuangan Pemerintah Daerah Dalam Pelaksanaan Otonomi Daerah (Studi Pada Dinas Pendapatan Daerah Dan Badan Pengelola Keuangan Dan Aset Daerah Kota Malang Tahun Anggaran 2008-2012). Jurnal Administrasi Publik Mahasiswa Universitas Brawijaya, 2(2).

Simanjuntak, Rober Arthur. (2010). Desentralisasi Fiskal Dan Manajemen Makroekonomi; Urgensi Suatu Grand Design Di Indonesia. Jurnal Prisma, 29(3).

Sumardi. (2014. Determinan Efektivitas Pengaruh Kebijakan Desentralisasi Fiskal Terhadap Kemampuan Keuangan Daerah Serta Dampaknya Pada Pertumbuhan Ekonomi Daerah (Studi Kasus: Kabupaten/Kota Di Jawa Tengah). Journal of Rural and Development, $5(2)$.

Syaifullah, Ahmad, and Nazaruddin Malik. (2017). Pengaruh Indeks Pembangunan Manusia Dan Produk Domestik Bruto Terhadap Tingkat Kemiskinan Di ASEAN-4 (Studi Pada 4 Negara ASEAN). Jurnal Ilmu Ekonomi, 1(1). Retrieved from http://ejournal.umm.ac.id/index.ph p/jie/article/download/6071/5525.

Tenrini, Rita Helbra. (2014). Pemekaran Daerah: Kebutuhan Atau Euforia Demokrasi? Mengapa Harus Mekar. Pusat Kebijakan APBN BKF Republik Indonesia.

Wekan, ReinJoseph, et al. (2018). The Effect of Fiscal Decentralization on Economic Growth and Econom Ic Disparity in Maluku Province. International Journal of Advanced Research, 6 (10), pp. 581-87, doi:10.21474/ijar01/7843.

World Bank. (1997). World Development Report. Oxford University Press, doi:10.1192/bjp.111.479.1009-a. 